\title{
Генофонд тыквы коллекции ВИР для селекции на многоплодность
}

\author{
The gene pool of a squash of the VIR collection for breeding on many fruits setting
}

\section{Пискунова Т.М., Мутьева З.Ф.}

\section{Аннотация}

Для расширения ареала возделывания и продвижения культуры тыквы в северные районы страны нужны холодостойкие и ультраскороспелые сорта. Цель работы: изучение коллекции тыквы ВИР и выделение источников многоплодности для снабжения селекционеров ценным исходным материалом. Материал исследований: образцы тыквы коллекции ВИР различного географического происхождения. Исследования проводили в 2006-2016 годах на полях научно-производственной базы «Пушкинские и Павловские лаборатории ВИР» (СанктПетербург). Почвенно-климатические условия зоны изучения - типичные для региона. Почвы - дерново-подзолистые, супесчаные. Сумма температур за вегетационный период (майсентябрь) - 2020-2065 ${ }^{\circ} \mathrm{C}$ (средняя $2049{ }^{\circ} \mathrm{C}$ ). Сумма осадков варьировала от 275 до 355 мм (средняя 325 мм). Способ выращивания - безрассадный, агротехника общепринятая для культуры. Морфологическое описание образцов и оценку их по биологическим и хозяйственно ценным признакам проводили согласно методическим указаниям ВИР и классификатору культурных видов рода Cucurbita. В результате изучения образцов тыквы коллекции ВИР выделены 47 многоплодных образцов, формирующих на растении 5-8 порционных плодов. Из них наибольшей многоплодностью отличались: Baby Hubbard (к-4860), Vegetable Spaghetti (к-3353) и Little Gem (к-4383) из Канады, Baby Pam (к5170), Bush everbearing (к-2438) и Mini jack (к-4812) из США, Красная (вр.к-2072), Красная драгоценность (к-5383) и Красная новинка (к-5384) из Китая, Cachi INTA (к-4269) и Cachi Magni INTA (к-4105) из Аргентины, Сластена (к-4935), Дюймовочка (к-5116), б/н (к-2787) из России, Dynia Makaronova (к-4471) из Польши, Местная (к-4927) из Болгарии. Стабильно высокий уровень продуктивности показали образцы Baby Hubbard (Канада), Cachi Magni INTA (Аргентина), Красная весенняя (Бельгия), Cachi INTA (Аргентина), Местная (Россия), Местная (Болгария). Кустовой габитус растения, способствующий более длительному периоду механизированной обработки, отмечен у 13 многоплодных образцов. Все многоплодные образцы отличались хорошими и отличными вкусовыми качествами (4-5 баллов). Проведена сравнительная оценка этих образцов по уровню спелости, продуктивности, качеству плодов. Выделены и рекомендованы в качестве исходного материала для селекции образцы, отличающиеся раннеспелостью, стабильной продуктивностью, имеющие кустовой габитус растения и высокие вкусовые качества.

Ключевые слова: тыква, коллекция, продуктивность, качество плодов, исходный материал.

Для цитирования: Пискунова Т.М., Мутьева З.Ф. Генофонд тыквы коллекции ВИР для селекции на многоплодность // Картофель и овощи. 2020. №1. С. 32-34. https://doi.org/10.25630/ PAV.2020.12.31.001

\section{Piskunova T.M., Mytieva Z.F.}

\section{Abstract}

To expand the area of growing and promote pumpkin crop in the Northern regions of the country, cold-resistant and ultraripe cultivars are needed. The purpose of the work: to study the collection of pumpkin of VIR and identify sources of many fruits setting to supply breeders with valuable source material. The research material: samples of pumpkin collection of VIR of different geographical origin. The research was carried out in 2006-2016 in the fields of scientific and production base "Pushkin and Pavlovsky laboratories VIR» (St. Petersburg). Soil and climatic conditions of the study zone are typical for the region. The soils are sod-podzolic, sandy loam. The sum of temperatures for the growing season (may-september) - 2020 $2065{ }^{\circ} \mathrm{C}$ (average $2049{ }^{\circ} \mathrm{C}$ ). The amount of precipitation varied from 275 to $355 \mathrm{~mm}$ (average $325 \mathrm{~mm}$ ). Method of cultivation - non seedlings, agricultural machinery common to the culture. The morphological description of the samples and their assessment on biological and economically valuable features were carried out according to the methodical instructions of the VIR and the classifier of cultural species of the genus Cucurbita. As a result of the study of pumpkin samples of the VIR collection, 47 multi-fruit samples were identified, forming 5-8 portion fruits on the plant. Of these, the most prolific were: Baby Hubbard (K-4860), Vegetable Spaghetti (K-3353) and Little Gem (K-4383) from Canada, Baby Pam (K-5170), Bush everbearing (K-2438) and Mini jack (K-4812) from the United States, Red (t.k-2072), Red jewel (K-5383) and Red novelty (K5384) from China, Cachi INTA (K-4269) and Cachi Magni INTA (K-4105) from Argentina, Slastena (K-4935), Dyujmovochka (K5116), b/n (K-2787) from Russia, Dynia Makaronova (K-4471) from Poland, Local (K-4927) from Bulgaria. Consistently high level of productivity showed samples Baby Hubbard (Canada), Cachi Magni INTA (Argentina), Red spring (Belgium), Cachi INTA (Argentina), Local (Russia), Local (Bulgaria). Bush habitus of the plant, contributing to a longer period of mechanized processing, was noted in 13 multi-fruits specimens. All multiple samples had good and excellent taste qualities (4-5 points). The comparative assessment of these samples on the level of ripeness, productivity, quality of fruits is carried out. Selected and recommended as a starting material for breeding samples, characterized by early maturity, stable productivity, having a bush habit of the plant and high taste.

Key words: squash, collection, productivity, quality of fruits, initial material.

For citing: Piskunova T.M., Mut'eva Z.F. The gene pool of a squash of the VIR collection for breeding on many fruits setting. Potato and Vegetables. No1. Pp. 32-34 (In Russ.). https://doi.org/10.25630/ PAV.2020.12.31.001
И спользование новых сортов и гибридов бахчевых культур позволяет без существенных дополнительных затрат увеличить урожайность на 15-20\% [1]. Для ускорения селекционного процесса и повышения эффективности бахчеводс- тва необходимо вести селекционную работу с учетом меняющихся приоритетов развития селекции и ее направленности [2]. Основные направления в селекции тыквы - создание раннеспелых высокоурожайных сортов и гибридов интенсивного типа, адаптивных к условиям внешней среды, пригодных для механизированного возделывания и уборки [3]. Для расширения ареала возделывания и продвижения культуры тыквы в северные районы страны нужны холодостойкие и ультраскороспелые сор- 
та. Актуальное направление современной селекции - создание многоплодных сортов тыквы с небольшими плодами, которые наиболее технологичны при уборке, транспортировке и переработке. Цель работы: изучение коллекции тыквы ВИР и выделение источников многоплодности для снабжения селекционеров ценным исходным материалом.

\section{Условия, материалы и методы} исследований

Материалом исследований послужили образцы тыквы коллекции ВИР различного географического происхождения. Исследования проводили в 2006-2016 годах на полях научно-производственной базы «Пушкинские и Павловские лаборатории ВИР» (Санкт-Петербург). Почвенно-климатические условия зоны изучения - типичные для региона. Почвы - дерново-подзолистые, супесчаные. Сумма температур за вегетационный период (май-сентябрь) - 2020-2065 ㄷ (средняя 2049 $\left.{ }^{\circ} \mathrm{C}\right)$. Сумма осадков варьировала от 275 до 355 мм (средняя 325 мм). Способ выращивания - безрассадный, агротехника общепринятая для культуры. Морфологическое описание образцов и оценку их по биологическим и хозяйственно ценным признакам проводили согласно методическим указаниям ВИР и классификатору культурных видов рода Cucurbita L. [4, 5].

Эффективность селекции для создания конкурентоспособных сортов зависит от генетического разнообразия исходного материала, его изменчивости, степени изученности морфологических, биологических и хозяйственно полезных признаков. Использование генетических коллекций - один из основных ресурсов для создания новых сортов и гибридов бахчевых культур [6]. Обширный и постоянно пополняющийся генофонд тыквы коллекции ВИР, насчитывающий в настоящее время 2944 образца из 99 стран мира, позволяет успешно проводить работу по созданию генетических источников и доноров наиболее важных селекционных признаков.

В условиях короткого вегетационного периода СевероЗападного региона РФ большая часть сортов тыквы с плодами массой 3,5-5 кг и более успевает сформировать на растении только 1-2 зрелых плода. Сорта с мелкими плодами, как правило, более раннеспелые, а за счет большего числа завязавшихся и вызревших плодов они могут иметь довольно высокую продуктивность.

\section{Результаты исследований}

В результате многолетнего изучения образцов тыквы крупноплодной и тыквы твердокорой из коллекции ВИР выделены 47 многоплодных образцов, формирующих на растении 5-8 порционных плодов. Из них наибольшей многоплодностью отличались: Baby Hubbard (к-4860), Vegetable Spaghetti (к-3353) и Little Gem (к-4383) из Канады, Baby Pam ( $\mathrm{k}-5170)$, Bush everbearing ( $\mathrm{k}-2438)$ и Mini jack (к-4812) из США, Красная (вр.к-2072), Красная драгоценность (к-5383) и Красная новинка (к-5384) из Китая, Cachi INTA (к-4269) и Cachi Magni INTA (к-4105) из Аргентины, Сластена (к-4935), Дюймовочка (к5116), б/н (к-2787) из России, Dynia Makaronova (к-4471) из Польши, Местная (к-4927) из Болгарии.

Географическое происхождение изученных коллекционных образцов тыквы было различным, но среди выделившихся по многоплодности наблюдалась определенная тенденция, свидетельствующая о разных приоритетах в селекции по этому признаку в различных регионах. Так, из 47 многоплодных образцов 17 происходили их стран Северной Америки (Аргентина, США и Канада), 13 - из стран Восточной Азии (Китай, Япония, Южная Корея), 10 - из России. Из стран Западной и Восточной Европы в выборке присутствовали лишь единичные образцы. Следует отметить, что в российской селекции в последние годы значительно активизировалась работа по созданию многоплодных сортов с порционными плодами.

Для нашей страны, характеризующейся большим разнообразием почвенно-климатических условий, необходимы скороспелые сорта и гибриды для выращивания ранней продукции в районах с коротким вегетационным периодом. Анализ распределения многоплодных образцов по группам спелости показал, что большая часть образцов (31) отличались раннеспелостью. Из них 6 образцов были очень ранними (период от массовых всходов до созревания первого плода - 85 дней), 14 образцов отнесены в группу раннеспелых (90 дней), 11 - в группу среднеранних (95-100 дней). Среднеспелостью (от всходов до созревания первого плода - 100-110 дней) характеризовалось 16 образцов. Позднеспелых образцов среди многоплодных не было. Среди раннеспелых по скорости про- хождения фенофазы всходы - созревание первого плода выделились Cheyenne Bush (к-3589) из Канады, Веснушка (к-4722), Улыбка (к-4721) и Дачная (к-4941) из России, Cachi INTA (к-4269) из Аргентины, Красная новинка (к-5384) из Китая.

Продуктивность образцов варьировала в зависимости от года выращивания. У отдельных образцов этот размах был довольно значительным: Красная новинка (к-5384, Китай) от 4,5 до 15 кг с растения, Mini jack (к-4812, США) - 5,6-12,4 кг, Dynia Makaronova (к-4471, Польша) - 9,622,4 кг, Красная (вр.к-2072, Китай) 7,2-15,0 кг, Зеленая звезда (к-5339, Китай) - 8,8-18,5 кг.

Наибольший интерес представляют образцы, имеющие высокую урожайность при различных, не всегда благоприятных погодно-климатических условиях. По результатам исследований к стабильно сохраняющим высокий уровень продуктивности отнесены образцы Baby Hubbard (к-4860, Канада) 16,8-19,2 кг с растения, Cachi Magni INTA (к-4105, Аргентина) - 16,021,0 кг, Красная весенняя (к-4657, Бельгия) - 12,5-15,0 кг, Cachi INTA (к-4269, Аргентина) - 10,0-17,5 кг, Местная (к-2787, Россия, Дальний Восток) - 11,2-13,3 кг, Местная (к4927, Болгария) - 11-12,9 кг. Эти образцы - ценный исходный материал для создания адаптивных сортов и гибридов применительно к разным регионам страны, в том числе для условий Северо-Запада РФ.

В настоящее время интерес для селекции представляют сорта/гибриды тыквы, пригодные для механизированного выращивания, с кустовым габитусом растения. Среди выделившихся по многоплодности образцов 13 сортов характеризовались кустовостью. По степени выраженности этого признака образцы разделились на три группы. К первой были отнесены следующие образцы - Cachi Magnif INTA (к-4105) из Аргентины, Красная драгоценность (вр.к-2076) и Красная новинка (вр.к2077) из Китая, Cheyenne Bush (к3589) из Канады, Веснушка (к-4722) и Улыбка (к-4721) из России (селекции ВНИИССОК) имели полностью кустовой тип растения. Образцы второй группы - Bush everbearing (к2438), Sweet Mama (к-4134), Cachi INTA (к-4269) из Аргентины также были кустовыми, плоды у них завязывались у основания куста, но к концу периода вегетации они формировали небольшую, длиной до 1,5 м, 


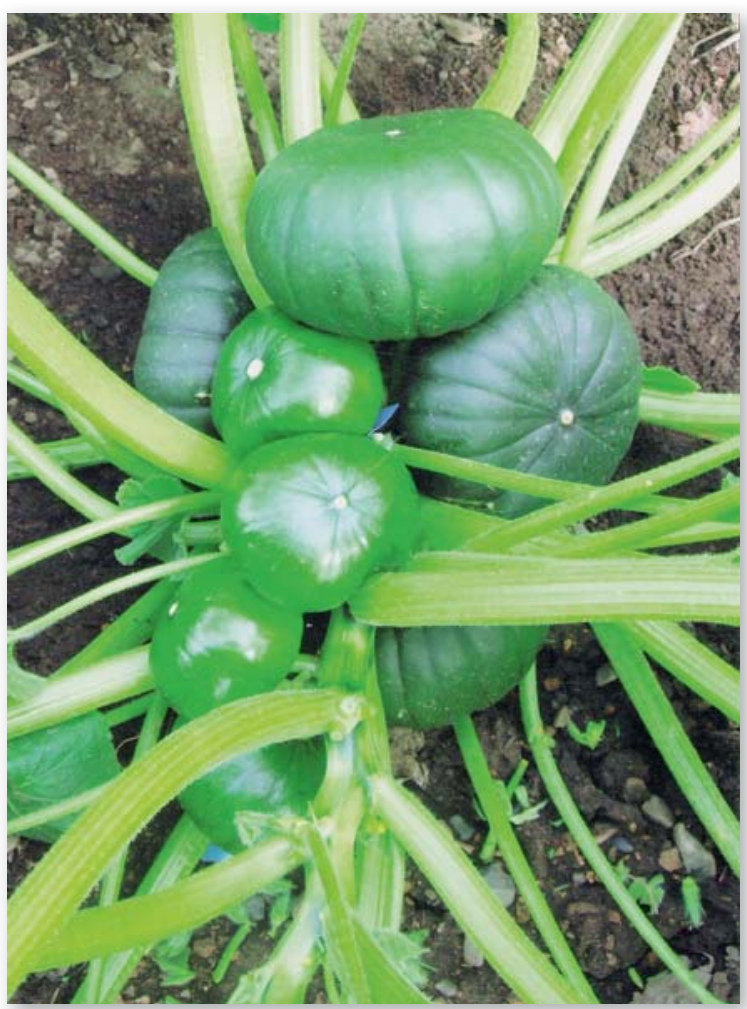

Cachi Magnif INTA (к-4105, Аргентина)

плеть без плодов. В третью группу вошли кустовые образцы, формирующие до трех очень коротких (1,5 м) плетей: Naked Seeded 293A (к-4707) из Канады, Baby Pam (вр.к-1176) из
США и Зеленая столовая (вр.к-2080) из Китая.

Важные качественные характеристики плодов тыквы: вкус, аромат и консистенция мякоти. Все многоплодные образцы по результатам дегустационной оценки характеризовались хорошим (4 балла) и отличным (5 баллов) вкусом. Особо следует отметить образцы из Китая - Золотое сердце (вр.к-2073), Красная драгоценность (к-5383) и Красная маленькая (вр.к-2079), имеющие ярко-оранжевую плотную хрустящую мякоть с ореховым вкусом. Сорта Сластена и Дюймовочка селекции ВИР отличались толстой (4-6 см) ароматной мякотью и сладким вкусом.

\section{Выводы}

Таким образом, в результате изучения коллекции ВИР выделены 47 многоплодных образцов, формирующих на растении 5-8 плодов массой 1-2,8 кг. Большая часть образцов (31) отличались раннеспелостью, из них 6 были очень ранними (период от массовых всходов до созревания первого плода 85 дней). Варьирование по продуктивности было довольно зна-

\section{Библиографический список}

1.Быковский Ю.А., Малуева С.В., Никулина Т.М. Товарному бахчеводству России - продуктивные сорта // Картофель и овощи. 2014. №6. С. 32-34.

2.Значение селекции бахчевых культур в развитии отрасли бахчеводства / Т.Е. Клебошина, Г.С. Егорова, Е.А. Варивода, Д.С. Шапошников // Известия Нижневолжского агроуниверситетского комплекса: наука и высшее профессиональное образование. 2017. №1 (45). С. 1-7.

3.Коротцева И.Б., Химич Г.А. Основные направления и задачи селекции тыквенных культур // Овощи России. 2013. 2 (19) С. 17-20.

4.Изучение и поддержание коллекции бахчевых культур. Методические указания / сост. Т.Б. Фурса, М.И. Малинина, З.Д. Артюгина. Л.: ВИР, 1988. 32 с.

5.Широкий унифицированный классификатор СЭВ культурных видов рода Cucurbita L. / сост. Л.М. Юлдашева, В.А. Корнейчук, Е. Пекаркова. Л.: ВИР, 1989. 21 с.

6.Никулина Т.М., Галичкина Е.А. Роль исходного материала в селекции высокопродуктивных сортов тыквы // Селекция и семеноводство овощных культур. М., 2015. С. 446-449.

\section{References}

чительным как по годам изучения, так и в зависимости от генотипа образца. Стабильно высокий уровень продуктивности показали образцы Baby Hubbard (Канада), Cachi Magni INTA (Аргентина), Красная весенняя (Бельгия), Cachi INTA (Аргентина), Местная (Россия), Местная (Болгария). Кустовой габитус растения, способствующий более длительному периоду механизированной обработки, отмечен у 13 многоплодных образцов. Все многоплодные образцы отличались хорошими и отличными вкусовыми качествами (4-5 баллов). Использование выделенных образцов в качестве исходного материала позволит ускорить селекционный процесс и сократить затраты при выведении новых сортов и гибридов.

\section{Благодарности}

Работа выполнена в рамках государственного задания по тематическому плану ВИР по теме № 0662-2019-0003 «Генетические ресурсы овощных и бахчевых культур мировой коллекции ВИР: эффективные пути расширения разнообразия, раскрытия закономерностей наследственной изменчивости, использования адаптивного потенциала», номер государственной регистрации ЕГИСУ НИОКР AAAA-A19-119013090157-1.

1.Bykovskij Ju.A., Malueva S.V., Nikulina T.M. Commodity melons of Russia-productive varieties. Potato and vegetables. 2014. No6. Pp. 32-34 (In Russ.).

2. The importance of selection of melons in the development of melon industry / T.E. Kleboshina, G.S. Egorova, E.A. Varivoda, D.S. Shaposhnikov. Proceedings of the lower Volga agricultural University complex: science and higher professional education. 2017. No1 (45). Pp. 1-7 (In Russ.).

3. Korotseva I.B., Himich G.A. Main directions and tasks of pumpkin crops breeding. Vegetables of Russia. 2013. 2 (19). Pp. 17-20 (In Russ.).

4.Study and maintain a collection of melons. Methodical instructions / compilers T.B. Fursa, M.I. Malinina, Z.D. Artjugina. Leningrad. VIR. 1988. 32 Pp. (In Russ.).

5.Wide unified classifier of COMECON cultural species of the genus Cucurbita L. Leningrad. VIR. 1989. 21 Pp. (In Russ.).

6.Nikulina T.M., Galichkina E.A. The role of the source material in the selection of highly productive varieties of pumpkin. Selection and seed production of vegetable crops. Moscow. 2015. Pp. 446449 (In Russ.).

\section{Об авторах}

\section{Author details}

Пискунова Татьяна Миновна, канд. с.-х. наук, в.н.с. E-mail: tmpiskunova@yandex.ru

Мутьева Зинаида Федоровна, н.c. E-mail: zinaidavir@mail.ru Федеральный исследовательский центр «Всероссийский институт генетических ресурсов растений имени Н.И. Вавилова» (ВИР)

Piskunova T.M., Cand. Sci. (Agr.), leading research fellow. E-mail: tmpiskunova@yandex.ru

Mytieva Z.F., research fellow. E-mail: zinaidavir@mail.ru Federal Research Centre the N.I. Vavilov All-Russian Institute of Plant Genetic Resources (VIR) 